\title{
IDENTITY SALAFIYAH ON PIERRE BOURDIEU PERSFECTIVE CASE STUDY ON SALAFISM COMMUNITY IN INDONESIA
}

\author{
Yoyoh Hereyah and Fini Diah Endrastiti \\ Universitas Mercu Buana Jakarta, Indonesia
}

\begin{abstract}
The phenomenon which becomes the object is the identity contestation Salafiyah veiled women in the Salafism community in Public Space. The concept of habitus and field's Pierre Bourdieu has a very important role, because this concept describes how the cultural production in the social world. Habitus is the rules inherent in a person and structured tendency to think, feel and act in certain ways, which then encourages the individual to behave and act in the social field. While the field is structured realm where individuals behave to controlled. ConstructivistStructuralist paradigm-particularly relevant used in this study because it provides viewpoints and limits palpable in research to explore the phenomenon of veiled women in public space. Research carried out by focus on a small portion of the community Salafiyah Muslim groups. Based on this research can be concluded that the communication in the group that carried out by Salafiyah community members indeed have a very important role to push contestation identity of veiled women in public domain. Reproducing the Habitus based system, which is constructed by the individual earlier and inherited by channeling message agencies to community's Salafiyah now and will continue in the next Salafiyah community members.
\end{abstract}

Keyword: Salafiyah, Identity, Muslim

\section{INTRODUCTION}

In Indonesia, in particular, although it is a country with the largest Muslim population in the world, Hijabi (non-veil) more hijab with additional veil is a new thing and considered as a culture that comes from the Arabian Peninsula. Some opinions on the veil are as Arabic culture by some people, considered something new-popular that is not a culture of Indonesia. Shaykh Al-Bilali (2014: VI) instead rejected the opinion that the hijab and veil only a cultural discussion, Shaykh Uthaymeen confirms that one interesting is precisely the Salafiyah community argues that veil or niqab is The old culture that has existed since the time of the Prophet Muhammad when the decline of hijab order, not only is a popular culture because it was used by the wife of the Prophet (Ibn ' Abbas in Shaykh ' Uthaymeen, 2015:23).

. It has been known in general some communities in Indonesia such as Salafiyah, Jamaa'ah Tabliq, Hizbut Tahrir, and so on. One of the most famous community in the recommendation of the use of veil by women especially for Muslim Salafiyah community. Female members of the Salafiyah community and Muslimah are generally encouraged to use the veil in all its activities ${ }^{1}$ outdoors. They are confidently in places where they are easily found. There are important and very interesting thoughts of Pierre Bourdieu that if able to give a picture of this phenomenon is Habitus and Arena, which according to Pierre Bourdeu:

Habitus is a social value that is adopted by humankind and reproduced through a continuous socialization process that lasts a long time, so that it becomes the way of thought and pattern of attitudes that exist in human beings. Habitus that has been embedded and so strong in human beings is called Hexis where in Hexis of personal things are interwoven with social. Habitus guides the individual to do a thing (Jenkins, 1992).

. Bourdieu stated that only when the man didhe might know about a thing (Jenskins,1992). The veiled habitus leads to how the habits, the values, the routines that Muslim women have in place in their communities, the discussion and culture of the groups built in their communities. Every society, every culture, and any group of individuals who acknowledge themselves as collectivity have their own definitions of the world and what their position is like in it. Habitus underlies a public domain consisting of relational networks that communicate in a social order. Habitus allows people to live spontaneously in everyday life interacting with individual outside parties (Mahar 1985: XIX)

${ }^{1}$ http://muslim.or.id/6207-hukum-memakai-cadar-dalam-pandangan-4-mazhab.html 
In addition to Habitus, the famous also of Pierre Bourdieu's thought was the existence of the Arena. In this arena a number of individuals with their respective habitat interact to produce a diversity of actions in accordance with the condition of the arena (Harker, at.al, in Takwin 2005: XX) for Bourdieu Arena is a social system structured controlled by individuals or institutions (Jenkins,1992). CAdar is One of them, the social system in which these women are in them is an arena of identity contestation, the arena where they fight for and maintain the proper use and interpretation And best for him and his group that the attributes they use as well as the identity-forming and his group. Identity is a person who has been possessed by someone since he was born and is well deserved for grabs and fought. Identity can be born, built and strengthened in interactions with other individuals within a community. Identity is born from the process of interaction with others. The identity of a person may be more than one and different between one individual and another (Van Dijk, 2011:265).

Often It is heard that Stigma is sometimes impressed to the users of the veil as if - though, get an edification of various circles in the public domain. In fact, there is a lot of things that are being promoted by community members regarding the use of the Veil (Jenkins, 1992:156). This encourages the contestation of female identities in the public domain to prove that they are harmless. The contestation of identity in the public sphere for interpretation and the best meaning of the identity is for himself and his group. The woman who tried to show her identity as a good muslimah. This raises the belief that identity contestation should be done by the users of the good contestation with people outside of the Salafiyah community or the contestations it does in the Salafiyah community itself because Sunnah Shar'iyah he believes. The contestation itself in the English Dictionary of the origin of the original Indonesian word is the contest which means the race (kbbi.web.id). The definition of contestation according to Oxford Dictionaries is said that contestation is an action or process that is disputed (disputing) or arguing (Argung).

The phenomenon of women in the public domain is a big phenomenon that is around us that are rarely noticed by people who think that veil and hijab is a simple thing. Therefore, the research attempts to dig deeply and disassemble the communication of the Salafiyah community members to produce habitus that contribute to encouraging members of the Salafiyah community to be able to contestation in the public sphere as an arena Contestation of his identity to gain meaning and good interpretation of self and community.

\section{THEORETICAL FRAMEWORK}

In regard to previous studies can be made matrix as follows:

\begin{tabular}{|c|c|c|c|c|}
\hline Title & Source & Research methods & Research results & Position of Weelitian \\
\hline $\begin{array}{l}\text { 1. GENDER IN } \\
\text { RACE IN UK } \\
\text { ORGANISATION: } \\
\text { CASE STUDY OF } \\
\text { NIGERIAN AND } \\
\text { INDIAN WOMEN }\end{array}$ & $\begin{array}{l}\text { Gender \& } \\
\text { Behaviour 2014, } \\
12(1), 6045-6058 \\
\text { Copyright Ó } 2014 \\
\text { Ife Center for } \\
\text { Psychological } \\
\text { Studies/Services, } \\
\text { Ile-Ife niger } \\
\text { ISSN: 1596-2931- } \\
\text { ProQuest-e- } \\
\text { resourches.pnri.g } \\
\text { o.id }\end{array}$ & $\begin{array}{l}\text { NARRATIVE } \\
\text { APPROACHES } \\
\text { WITH } \\
\text { QUALITATIVE } \\
\text { APPROACHES }\end{array}$ & $\begin{array}{l}\text { 1. The effort to have a } \\
\text { successful career is a } \\
\text { conscious effort on the part of } \\
\text { some women and because of } \\
\text { the need to adopt a strategy for } \\
\text { this benefit. } \\
\text { 2. The organization also plays } \\
\text { a key role in the career of } \\
\text { women as several respondents } \\
\text { attempt to find the right } \\
\text { location for career success in } \\
\text { the capture of challenges } \\
\text { related to the observation of an } \\
\text { organization's location in an } \\
\text { area With more EM groups } \\
\text { serving as a better location for } \\
\text { career success for an EM } \\
\text { women. } \\
\text { 3. There are still respondents } \\
\text { who have discrimination or } \\
\text { stereotypes because of their } \\
\text { gender and ethnicity. } \\
4 \text {. This research shows how } \\
\text { the EMW (Ethnic Minority } \\
\text { Women) career victims of this } \\
\text { stereotype are usually negative } \\
\text { or underestimating and such } \\
\text { stereotypes have the ability to } \\
\text { harm a person as some women } \\
\text { (respondents) state it. } \\
5 . \text { The competition that } \\
\text { women face in their } \\
\text { organization is the } \\
\text { organizational hierarchy } \\
\text { arrangement. Some women }\end{array}$ & $\begin{array}{l}\text { The position is the same, } \\
\text { and the difference: if the } \\
\text { study emphasizes women's } \\
\text { career in an organization } \\
\text { with the issue of gender } \\
\text { and ethnic discrimination, } \\
\text { while the research that will } \\
\text { be done by me emphasizes } \\
\text { the ability of women } \\
\text { (veiled) to Survive in the } \\
\text { public domain in this } \\
\text { regard in urban areas. }\end{array}$ \\
\hline
\end{tabular}




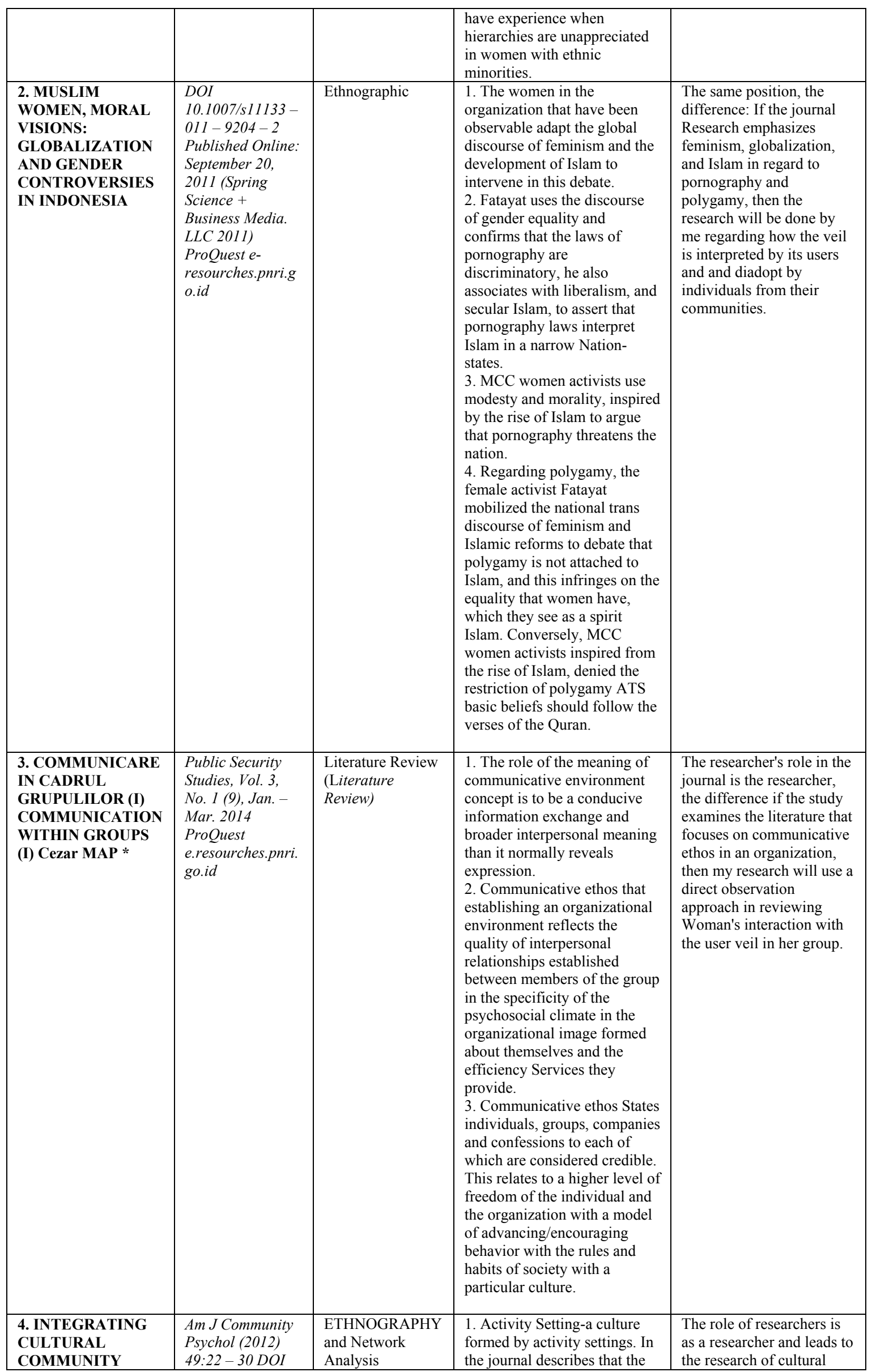




\begin{tabular}{|c|c|c|c|c|}
\hline $\begin{array}{l}\text { PSYCHOLOGY: } \\
\text { ACTIVITY } \\
\text { SETTINGS AND } \\
\text { THE SHARED } \\
\text { MEANINGS OF } \\
\text { INTERSUBJECTIV } \\
\text { E }\end{array}$ & $\begin{array}{l}10.1007 / \text { s } 1064- \\
011-9434-1 \\
\text { Publish Online: } \\
15 \text { March } 2011 \text { @ } \\
\text { Society for } \\
\text { Community } \\
\text { Research an } \\
\text { Action 2011 }\end{array}$ & & $\begin{array}{l}\text { culture of youth is formed by } \\
\text { an expression of music, style } \\
\text { of dress, interest in a thing } \\
\text { (hobbies). } \\
2 \text {. Human interactions are the } \\
\text { source of activity and affect } \\
\text { social networking and } \\
\text { psychology development from } \\
\text { participants. } \\
\text { 3. For many young men, } \\
\text { Intersubjectivity develops with } \\
\text { colleagues in social } \\
\text { association. } \\
4 \text {. Through the tracking } \\
\text { system, those who are ignored } \\
\text { or harassed at home often } \\
\text { make connections with fellow } \\
\text { young men - alike } \\
\text { experiencing it. }\end{array}$ & $\begin{array}{l}\text { psychology, the difference } \\
\text { with the research that will } \\
\text { be done by me is research } \\
\text { in the science of } \\
\text { communication with a } \\
\text { focus on women with } \\
\text { veiled in urban. }\end{array}$ \\
\hline $\begin{array}{l}\text { 5. THE MEANING } \\
\text { OF HIJAB: VOICE } \\
\text { OF MUSLIM } \\
\text { WOMEN IN EGYPT } \\
\text { AND yamen }\end{array}$ & $\begin{array}{l}\text { Journal of } \\
\text { International } \\
\text { Women's } \\
\text { StudiesVol. 16, } \\
\text { No. } 2 \text { January } \\
2015\end{array}$ & $\begin{array}{l}\text { Quantitative } \\
\text { approach, Survey }\end{array}$ & $\begin{array}{l}\text { 1. The meaning of hijab for } \\
\text { Egyptian and Yemeni women }\end{array}$ & $\begin{array}{l}\text { The research that will be } \\
\text { used in my research is a } \\
\text { qualitative approach with } \\
\text { the focus of how the } \\
\text { woman is patternised to } \\
\text { build a good meaning for } \\
\text { her veil, herself, and the } \\
\text { group. }\end{array}$ \\
\hline $\begin{array}{l}\text { 6. THE IMPACT OF } \\
\text { CULTURE ON } \\
\text { GROUP } \\
\text { BEHAVIOR: THE } \\
\text { COMPARISO OF } \\
\text { THREE ETHNIC } \\
\text { GROUPS }\end{array}$ & $\begin{array}{l}\text { Journal of } \\
\text { Conseling and } \\
\text { Development: } \\
\text { JCD; Spring } \\
\text { 2003, 81, 2, } \\
\text { ProQuest, pg. } 208\end{array}$ & Quantitative & $\begin{array}{l}\text { 1. Results of self-disclosure in } \\
\text { contrast to the first hypothesis } \\
\text { and the second hypothesis. } \\
2 \text {. The Affiliate results in } \\
\text { accordance with the first } \\
\text { hypothesis and hypothesized } \\
\text { to two rejected. } \\
\text { 3. Advantage of the } \\
\text { experience results-refer to the } \\
\text { results }\end{array}$ & $\begin{array}{l}\text { Research conducted by me } \\
\text { will be using a qualitative } \\
\text { approach }\end{array}$ \\
\hline $\begin{array}{l}\text { 7. HOW MUSLIM } \\
\text { WOMEN IN } \\
\text { AUSTRALIA } \\
\text { NAVIGATE } \\
\text { THROUGH MEDIA } \\
\text { (MIS) } \\
\text { REPRESENTATION } \\
\text { S OF } \\
\text { HIJAB/BURQA }\end{array}$ & $\begin{array}{l}\text { Australian } \\
\text { Journal of } \\
\text { Communication } \\
\text { Vol } 39 \text { (1) } 2012\end{array}$ & $\begin{array}{l}\text { Qualitative } \\
\text { approach, } \\
\text { determining } \\
\text { respondents with } \\
\text { snowball } \\
\text { technique }\end{array}$ & $\begin{array}{l}\text { Overall, the results show that } \\
\text { Muslim women value their } \\
\text { religious and/or cultural } \\
\text { identity as they strive to } \\
\text { integrate into Australian } \\
\text { society. They, however, do not } \\
\text { believe the media coverage of } \\
\text { Muslim women. Media, as a } \\
\text { cultural institution, plays a } \\
\text { very important role in the } \\
\text { immersion of the inter-ethnic } \\
\text { understanding necessary to } \\
\text { support Australia's } \\
\text { multicultural policies. }\end{array}$ & $\begin{array}{l}\text { The researcher's position is } \\
\text { the same as the researcher, } \\
\text { I examine the public } \\
\text { domain as the arena of } \\
\text { contestation of female } \\
\text { identities by using Pierre } \\
\text { Bourdieu's concept }\end{array}$ \\
\hline $\begin{array}{l}\text { 8. EFFECT OF } \\
\text { GENDER } \\
\text { DIVERSITY ON } \\
\text { PERFORMANCE } \\
\text { AND } \\
\text { INTERPERSONAL } \\
\text { BEHAVIOUR IN } \\
\text { SMALL WORK } \\
\text { GROUPS }\end{array}$ & $\begin{array}{l}\text { Sex Roles, Vol. } \\
\text { 52, Nos. 9/10, } \\
\text { May 2005 (C) } \\
\text { 2005) DOI: } \\
\text { 10.1007/s11199- } \\
0053732-8\end{array}$ & Quantitative & $\begin{array}{l}\text { 1. Since the latter effect is not } \\
\text { observed, further mediation } \\
\text { testing cannot be performed. } \\
\text { Thus the } 3 \text { hypothesis can not } \\
\text { be done. } \\
2 \text {. Women in mixed gender } \\
\text { groups are lacking in the } \\
\text { working orientation than } \\
\text { women in the same gender } \\
\text { group. However, men in } \\
\text { mixed gender groups are } \\
\text { more work-oriented than men } \\
\text { with the same gender group. } \\
3 \text {. For the fifth hypothesis the } \\
\text { test suggests that women } \\
\text { themselves/singles are less } \\
\text { talkative than most women, } \\
\text { whereas the men } \\
\text { themselves/singles speak } \\
\text { more than most men. Briefly } \\
\text { hypotheses } 4 \text { and } 5 \text { get } \\
\text { support }\end{array}$ & $\begin{array}{l}\text { Research in the journal } \\
\text { uses quantitative, while in } \\
\text { research I will do using a } \\
\text { qualitative approach of } \\
\text { analysis studies Pierre } \\
\text { Bourdieu }\end{array}$ \\
\hline
\end{tabular}




\begin{tabular}{|c|c|c|c|c|}
\hline $\begin{array}{l}\text { 9. The Construction } \\
\text { of Salafiya: } \\
\text { Reconsidering } \\
\text { Salafism From The } \\
\text { Perspective of } \\
\text { Conceptual History }\end{array}$ & $\begin{array}{l}\text { Int. J. Middle East } \\
\text { Stud. } 42 \text { (2010), } \\
\text { 369-389 doi: } \\
\text { 10.1017/S0002074 } \\
83810000401\end{array}$ & $\begin{array}{l}\text { Conceptual } \\
\text { History } \\
\text { Perspective }\end{array}$ & $\begin{array}{l}\text { 1. Discussing the Salafiyah } \\
\text { from a historical perspective. } \\
\text { 2. Conceptual history focuses } \\
\text { on the insistment and } \\
\text { construction of the } \\
\text { association/Salafi group and } \\
\text { raises the fundamental } \\
\text { question of "What we think } \\
\text { and know about Salafi". } \\
\text { 3. The construction of the } \\
\text { Salafiyah group could not be } \\
\text { interpreted in part - partly but } \\
\text { thoroughly ranging from the } \\
\text { origins of its emergence since } \\
\text { the early 20s. } \\
\text { 4. Distinguishing the } \\
\text { traditional Salafiyah and } \\
\text { Salafiyah jihadi. }\end{array}$ & $\begin{array}{l}\text { The approach that will be } \\
\text { used in my research is the } \\
\text { qualitative approach of } \\
\text { analysis studies Pierre } \\
\text { Bourdieu. The history of } \\
\text { Salafiyah in my research } \\
\text { will be used but as a } \\
\text { boundary directing and } \\
\text { enriching researchers to } \\
\text { know the history of the } \\
\text { formation of Salafiyah. But } \\
\text { in-depth discussions about } \\
\text { history are not done and } \\
\text { research will focus on the } \\
\text { construction and } \\
\text { reproduction of habitus in } \\
\text { the Salafiyah community, } \\
\text { especially women who are } \\
\text { members of the Salafiyah } \\
\text { community. }\end{array}$ \\
\hline $\begin{array}{l}\text { 10. Bourdieu and } \\
\text { Organization } \\
\text { Analysis }\end{array}$ & $\begin{array}{l}\text { Theor Soc (2008) } \\
\text { DOI: } \\
10.1007 / \mathrm{s} 11186- \\
007-9052-y\end{array}$ & $\begin{array}{l}\text { Studying the } \\
\text { organization with } \\
\text { the concept of } \\
\text { Pierre Bourdieu }\end{array}$ & $\begin{array}{l}\text { 1. Knowing the implications } \\
\text { of the theoretical framework } \\
\text { for relationships within an } \\
\text { organization. } \\
\text { 2. Position Habitus in an } \\
\text { organization - in the sense of } \\
\text { the organization here as an } \\
\text { arena and how members of } \\
\text { the organization take a role in } \\
\text { organizational conflicts. } \\
\text { 3. Shows that the concept of } \\
\text { Bourdieu has great } \\
\text { implications in the analysis of } \\
\text { the structure of relationships } \\
\text { within the Organization - the } \\
\text { strength of the structure, } \\
\text { change and reproduction of } \\
\text { individual actions in the } \\
\text { organization. }\end{array}$ & $\begin{array}{l}\text { I am a researcher here } \\
\text { arguing that this journal is } \\
\text { highly recommended for } \\
\text { reference to give a view on } \\
\text { the concept of Pierre } \\
\text { Bourdieu including for the } \\
\text { researchers themselves. } \\
\text { However, this journal } \\
\text { (limited) refers to the field } \\
\text { (arena) This is seen from } \\
\text { the absence of discussion } \\
\text { of the journal authors about } \\
\text { the concept of capital and } \\
\text { habitus. }\end{array}$ \\
\hline
\end{tabular}

From matrix in top look that research that will done very interesting to examined because from journc the dominated by study about group with context i.e discrimination women in organization, activists women $i$ organization about polygamy dan pornography, study group in context ethnic, behavior members group associate with influence training against behavior, while study about veil only 2 from 10 journal that examine abov niqabveil, and also 2 from 10 journal that contained that deemed have resemblance with topic that author kaj study on context meaning veil for users in yemen dan egypt with approach quantitative with techniques survey $t$ get data the respondennyadan misrepresentation niqabveil by media in australia with approach qualitative wit techniques snow ball as tool to determine the dan two next about salafiyah in context history dan analysis grou special as arena. from subject study literature above then position significance from research this that make $b$ indeed worth dan interesting to done research is research this will use approach qualitative same with 5 study the have displayed, with method research study case same with wrong one study group context discrimination $\mathrm{i}$ organization (no. 1 on matrix journal), research this have resemblance with two journal last (in matrix no. 9 an 10) however difference fundamental that need to emphasized about two journal last in matrix with research i i research i not discuss an deep about history emergence salafiyah dan surely clear research i will be at least - lac of complete journal last (no. 10) with subject that balanced about habitus and arenas so expected research i wi. have value novelty or novelty among all study above is research this will borrow concept pierre bourdieu abov habitus and arenas in group to aiming phenomenon affect identity dan phenomenon women veiled i.e how concer habitus and arenas played in community salafiyah with use paradigm constructivical-structuralist.

\section{PIERRE BOURDIEU'S CONCEPT}

Pierre Bourdieu has his own view of how social problems should be addressed. One feature of Bourdieu' thought is that the rational action of the actors is formed by its habitus and Habitus is formed by the outside worl through action. Actors are not one - the only person who has a role in a phenomenon but the previous social worl that was constructed by the former agent also contributed to the major influence. Bourdieu's view on the socic 
world is based on Habitus and the arena is not merely a pointed actor but also an eye for the established social world.

Essentially the concept of habitus according to Pierre Bourdieu is referring to the individual tendencies to happen in a way - a certain way that is created and formulated through a combination of objective structures and individual histories. These behavioural tendencies are derived from various social positions within a sphere, and and impact adjustments to that position. The place (Arena) and Habitus of one form the basis of other relationships. Habitus can be regarded as working on an individual unconscious (Mahar at. AL, 1990). Another notable concept that Pierre Bourdieu has brought about is the existence of the Arena (field). According to Bourdieu in the Jenskins (1992) The arena is a structured social system ruled by individuals or institutions where each of them is in a position of mastered and mastered, striving to acquire and The relationship between them is in a competition.

\section{Pierre Bourdieu}

Before further explaining the concepts of habitus and arenas, it is a good idea to describe Pierre Bourdieu, who is the founder of the cultural production theory. Pierre Bourdieu was a prominent philosopher who was born in Denguin, France on 1 April 1930. Bourdieu received a psychology education in Paris with Althusser, at the Ecole normale superiure. Bourdieu's work has largely processed various sources of thought from major figures such as Karl Marx, Durkheim, Weber, Saussure, Wittgenstein, Benveniste, from structural thought ranges, phenomenology to analytical philosophy. What is evident from Pierre Bourdieu is that Bourdieu managed to apply with consistent skeletal thinking, his theories and methods to all objects he discussed. Bourdieu called his own means as a constructivicist, which meant that there was still recognition of it as a structure, but different from the Saussurian or Levi Strausian traditions. Bourdieu's thought was a dizzing debate on the role of structural influences in shaping society (Jenkins, 1992).

Still in Jenkins (1992), it was explained that in the years 1958 - 1962, Bourdieu conducted ethnographic research on the conflict with the Kabyle community studies. In the study, Bourdieu gained a reputation for anthropology. Bourdieu taught at the University of Lille in 1960 and served as a study director in Ecole practique des Hautes estudes. Starting in 1968, Bourdieu started the center de sociologie europene , A research center founded by Aron. In 1981, Bourdieu headed the College De France.

For Bourdieu, humans are formed by disposition - diverse disposition. Meeting disposition - such disposition will form a diverse social world, multidimensional or multi-arena. That condition will bring up the sense of game. Through this the social arena became a complex while individuals developed their respective habitat that fit the position in the case. In his thinking Bourdieu always departs from the thought of conspetual innovation. Bourdieu has always linked his research to empirical studies, based on daily life.

\section{Habitus}

The concept of habitus is an alternative and reaction to the thought of placing the agent as a trager According to the Althusser or subconscious expression according to Levi-Strauss. Habitus seeks to understand the creative, active, and inventive abilities of human agents who are not universally individual minds. Bourdieu defines habitus as a theoretical intention to exit the philosophy of consciousness by not neglecting the agent, in its essence as a practical operator of the construction of Objects (Bourdieu, 1985:12).

Habitus is a disposition that encourages agents to act on certain situations in spontaneous (unplanned first) ways that reproduce practice and perception. The disposition represented by the habitus is: A. Enduring, B. Can be transferred to the various arenas, and C. To include the object that is the constituent of "structures in Structure" (Bourdieu, 2010: XVI).

With the concept of habitus borrowed from Bourdieu researchers hope to dismantle and make the best effort to understand the disposition of women in the Salafiyah community to enter the arena of identity contestation of public domain. The veiled Habitus was formed from the beginning by an earlier individual in the group, so the underlying knowledge of this action would bring out the Habitus which eventually became the driving engine to fight for good significance for Himself and his group.

\section{Arena}

According to Bourdieu in Jenkins (1992), individuals do not work in a vacuum but in social situations governed by a set of objective social relationships. Any social formation is structured by a hierarchical organized arena (economic arena, Arena group, educational Arena, cultural arena, etc.). The Arena according to Bourdieu (2010: XVI) is a structured space with the rules of its own function, with the relationship of power that is in it. Where this structure is determined by the position of the individual in the arena. The arena is dynamic depending on the position of the individual in the arena, changes in the individual position in the arena will cause changes in 
the arena structure. The formulation of the arena was Bourdieu's attempt to explain the cultural production. Each inner element in a system gets its meaning and function from the separation of the general perception or substance concerning the social world.

The public domain as an arena of identity contestation for women with a veil is the realm of struggle in their attempts to demonstrate that their existence in the public domain is normal and unnecessary to be feared. Habitus born and built in groups are the foundations of this action. The word contestation itself is not found in the large dictionary of Bahasa Indonesia. If we search in Google Translate then found the meaning of contestation is the objtion or debate ("The Action to Arguing or disputing"). The existence of women who are veiled and Muslims in the public domain are being held by the conditions of the community in which they have an activity that has meaning and interpretation, according to the experience gained from interacting directly with Female user Veil. People often hear news in electronic media about the conditions of the world being wary of terrorism. For example, what has recently happened as the Paris assault was reportedly killing hundreds of people and the Islamic State (IS, in the first ISIS) claimed responsibility for the incident. But none of the Islamic world leaders who agree with the attack when identified with the war of Islamic ways that are never taught by the Prophet Muhammad SAW.

\section{METHOD}

The type of research conducted on this research and can lead to a realistic and profound answer is qualitative. By Creswell (2010:19) qualitative research is a research strategy that also people often refer to as a research approach that is approaching, exploring, and understanding the meaning by a number of individuals or groups of people considered Social or humanitarian issues. In Neuman (2013:116) that the Interpretive approach is a systematic analysis of meaningful social action through human observation in detail and directly in the natural setting, in order to gain understanding and interpretation of how People create and defend their social world.

A suitable paradigm and can direct research into answers - the right answer is the constructional paradigm - structuralist, as the constructiphist paradigm looks at social reality is a form of construction as a result of the focus The analysis on the constructivicist paradigm is how and in what way a reality is constructed.

The research method used to answer questions - the question of researchers is to use A case study with multilevel Analysis. The reason for using the case study method is that the researched phenomenon is phenomenal. Then that this method has advantages - advantages are unique capabilities that can be fully connected with various types of evidence such as interviews and Observations (Yin, 2005:12). Still in Yin (2005:29), the case study is actually one - the only strategy that can dismantle and dig deeply everything that can give added value to the unique knowledge of individual phenomena, organizations, or individuals in the organization, and various other social fields relating to a specific matter.

Important data will be collected usingIn-depthinterviewswhere the focus of this technique is an observation of how engagement Members of the group in the reproduction and construction of Habitus as the foundation for Moslem women are able to survive and fight for the interpretation and the purposing of their identity. Data analysis is done through the processes and procedures in the treatment to pay attention to the basic concept as the foundation of the observation and research that is the concept analysis of Habitus and Pierre Bourdieu Arena.

\section{ANALYSIS AND DISCUSSION}

\section{Construction of a female identity in the Salafiyah community}

Pierre Bourdieu's concept in some of his earlier work reports on the importance of the central role that some parties both have in the reproduction and construction of habitus to transform behaviors and individual mindset to equalize perception and culture are implanted from one individual to another, from next generation to generation (Wilkes, C. Mahar, C, and Harker, R. In Takwin, B, 2005:109)

With regard to the Salafiyah community in this study, the predecessor habitus of the pre-dominant group that had existed in this group by individuals of the Salafiyah community group were accepted as one - the only truth believed to be sourced Purely from the Salafusholih. The reproductive process of habitus and its activities in it is similar to the Madrasah (Islamic school) which preserves the knowledge and experience of the previous generation in the succeeding generations In the Salafiyah community. The knowledge owned by individual agent of the message in this case para Ustad (teacher-teacher) or person who is deemed to have knowledge of Al Quran and Sunnah in depth "transferred" conveyed to the members of the Salafiyah community group With the belief that this knowledge must be instituted because it has such a high value for personal benefit both in the world that the regularity of life and in the Hereafter get heaven when doing it with the best of the world.

The role of individual message distributors here in reproducing and constructing habitus in the Salafiyah community group became a very meaningful role. Individual message dealers have a huge line of people to keep 
the members of the community Salafiyah from diverse backgrounds in order to be moved and shifted to an absolute belief that the Salafiyah community is the only way to find Divine truth.

Specialized in the reproduction and construction of the woman's habitus in the Salafiyah community, the authors observe the phenomenon of the veil from two main directions, the first how the speakers convey a special message of the women's aurate in Islam and the second How the communicable attitude in this community members in this salafiyah especially the women in response to messages-the message conveyed by the communicators. It is clear that the communicatial attitude here is to receive the message voluntarily and consider the message that the message conveyed by Ustad or ulama or the person deemed to have the depth of Shar'i sciences (Qur'an and Sunnah) is absolutely As long as the message presenter has been known is a Salafi. Question now how are the attitudes of the message dealers in the reproduction and construction of habitus?

In observation in field dan noted wrong one reviews study longer more less 1 hour more on youtube with sources ustad the ys titled hijab female muslimah there are many once emphasis - emphasis hard with illustration hard danger showing his loins dan why a women it required to close his loins. in minutes to 46 the sources explain about difference hijab and veil. where hijab it width dan cover entire body dan while veil described close head to to chest women dan explanation this strengthened with language nonverbal sources i.e cue hand that pass direction front face. on minutes to 48 explain how the women time prophet muhammad pbuh use veil above veil that close head to entire body to more meeting in keep awrah. wrong one example attitude special this equipped with acceptance like willingly from community i.e the women community salafiyah then will more easy reproduction dan construction habitusany) in community salafiyah start from transfer message by agent the presenter message dan continued to generation next that produce hexis on self individual members community salafiyah that then will encourage affect identity women veiled in realm public. habitus in self individual members community salafiyah not with itself formed, however results from blend from many things like power agent dealer message dan acceptance absolute from communicant dan of blend in self individual with arena social i.e community salafiyah. the habitus reproduced in community salafiyah is driver formation awareness, beliefsdan decision to out to arena social other with full believe self.

\section{Contestation of female identity in the Salafiyah community in groups}

From observations and interviews to several members of the Salafiyah community, it can be recalled that the individuals who act as message dealers have a significant and profound influence. They are directing to inviting and acting as motivators in building habitus in individuals so that individuals are encouraged to demonstrate their identity as a person who Obeuladani the Salafussholih and scholars who are believed to be scholars who follow the Sunnah of Rasulullah and the Tabi'in and Tabi'in in their public domain. Here's a description that explains how internal communication reproduces the formation of individual habitus in the Salafiyah community so that the habitus that form Hexis encourages individuals to fight for identity for themselves and its group:

In the communication and interaction of women with a veil in the Salafiyah community itself, there is a contestation that can be said to the naked eye but can be felt enough to be a communication to build habitus in the community through Communication in the Salafiyah community group. But this contestation is done to attract or raise or strengthen one another in the Salafiyah community. The result asked one of the referral Ustad a Salafi man named Ustad WR about strengthening Ukhuwah in Manhaj Salaf, following the outline of the interpretation results:

1. Invite to learn gradually. It begins by studying the Adab - Adab of the sciences and learning the right aqidah, making it wiser in the face of contention and differences can be interpreted to avoid disputes in the community.

2. If you want to invite someone to stay in the shade of the Salafiyah community or even this also applies to those who have not entered the community Salafiyah then the communication done should be adapted to the situation that is poor in science ( Community members). This awareness will keep them occupied by demanding and avoiding unprofitable affairs and avoiding unprofitable debates.

From the explanation of one of the informants Ustad WR above can be interpreted in the framework of identity contestation in the community Salafiyah itself more towards how to keep Ukhuwah (Brotherhood relations in Islam) and To minimize debate. This is sought with the intention of maintaining the confidentiality of relationships among members of the community that impact the group's loyalty and sentiment. Minimizing debates with people outside the community to avoid negative prejudice against individuals and groups of course that are behind him.

\section{Public domain as Arena identity contestation}

For women of Islam who wore clothes syar'i with additional close the face is the only way that is taken to achieve their purpose of life to please God and His messenger. This is what they believe, so that they do not care about any other person's views and sayings that are anti-resistant to the use of the veil, they only consider 
ways aimed at impressively veil are objects that are not Dangerous as well as the wearer by indicating that the user of the veil demonstrates the behaviour of the Islamic beauty.

The interpretation of researchers on Muslim women who are veiled, that what they do is a form of their belief in what they have believed to be one of God's commandments for women of women in the end times. For those hijab that accompanied by the veiled that they use is considered to have a distinctive value for their lives that without their veil as to loss of identity and their faith in the command of God and they believe that the hijab Accompanied by a veil will be able to bring them to the goals of the world and a good hereafter. They impress their fashion choices is a normal choice and it already should others appreciate and respect their choices. Using a veil does not reflect those who are terrible beings but there is their consistency to the Islamic teachings he believes.

According to Bourdieu (1984:169) in Habitus and a person's lifestyle is understood as a result of interactions between humans as subjects as well as objects in society, the result of conscious thought and the unconscious being formed throughout the history of the process Life. Bourdieu puts Life Styles in a series or a long social process involving capital, objective conditions, habitus, disposition, practices, Life Styles, system marks, and structure tastes. Likewise habitus in this veil, female users veil through lengthy processes and stages to decide to use a veil. Engaging the capital of knowledge, economics, and objective conditions, practices and lifestyles that support habitus form in the individual DNA encourages the user's Veil to act spontaneically in the context of the use of the veil up to the direction of inviting Women - other Muslim women, especially those who have no use of the veil to find virtue by the veiled.

For women who are concerned with the Salafiyah community, his decision in the veil is a manifestation of his obedience to the Shari'a of God and the apostle, so that the negative stigma of society against them is regarded as a form of temptation to their consistency in The veil that he wore and regarded him as a field of preaching in others who did not understand it. As Ustad YS expressed on the question of researchers about what can be done to be accepted in the community with the veil? Then how should the best attitude to face the challenge of social world that is less conducive to Muslim women who are veiled? His answers are as follows:

"(No other) wear, we can not make the community accept us. To adopt the Sunnah is a great reward in this day, where the practice of the Sunnah is very many tests.

Basically women are veiled aware of their circumstances that are considered strange to the social environment. However they try to fight the community's view by trying to demonstrate positive behavior that reflects the beauty of Islam in their fashion so that they hope the community will rate them more positively. In community life, female users of the veil also follow the rules in its environment with the terms of the rules and traditions according to the Islamic law that they understand even they are very respectful of government in Indonesia although still considered Has not followed Islamic sharia. As told by the informant $\mathrm{M}$, he and his associates who also veiled when there is a neighbor of their contras who held their celebration is also no less eager to help, as well as if there is a neighbor died they participated Visit and pray. But it is not undeniable that their busyness as a student makes them certainly better put their learning assignments from visiting without the right reasons to their neighboring neighbors so that they are stamped less associations by their neighbors. Muslim women in the veil also tried to maintain good relations with neighbors, all the informant in this study justify it. To establish a good relationship with the neighbor according to Sunnah. For them it is one of their efforts to realize their image as a good woman in the eyes of the general public, so for them is not true that those who have been veiled then do not want to interact with the community.

\section{BIBLIOGRAPHY}

Abidin, A. Firanda. 2015. The teachings of Mahzab the priest of the Syafi'i left. Second edition. Jakarta: Naashirussunah.

Al-Uthaymeen, M. Shalih. 2015. Veillaw. 11th edition. Solo: At - Tibyan.

Al Albani, N. Muhammad. Hijab women: According to the Qur'an and Sunnah. 7th edition. Solo: At-Tibyan.

Asyarif, M. 2013. 40 Hadith Women: Hadith potpourri, Jurisprudence, and chastity. First print. First edition. Jakarta: Ummul Qura

Chamin, B. 2007. Quantitative Research methods: Communication, economics, and public policy and otherSocial Sciences. Second edition. Jakarta: Kencana.

Creswell, W. John. 2010. Research Design Qualitative, quantitative, and Mixedapproaches. Third edition. Yogyakarta: Student Library.

Mulyana, Deddy et.al. (trans). R. Wayne Pace and Don F. Faules. 1993. Organizational communication: The Company's performance enhancing Strategy. Bandung.

R. Hilderiah. 2015. motivation: Presentation. University of Mercu Buana, Jakarta.

Gerring, J. 2007. Case Study Research: Principles and Practices. Cambride University Press 
Goldberg and Larson. 1985. Group Communication: Process-discussion and implementation. First print. Jakarta: UI Press

Jawas, Y. Abdul Qadir. 2012. Mulia with Manhaj Salaf. Sixth edition . Bogor: Pustaka At - Taqwa. Jenskins, R. 2004. READ PIERRE BOURDIEU's mind. First edition. Yogyakarta: Creation of discourse.

Harker, R; Mahar, C; Wilkes, C. 1990. (Habitus x capital) + Realm = Practice: The most comprehensive introduction to Pierre Bourdieu's thoughts. Yogyakarta: Jalasutra

Neuman, W. Lawrance. 2013. Social Research methodology: Qualitative and quantitativeapproaches. Seventh edition. Jakarta: PT. The index.

Subandi, I. 1998. Women and the Media: the construction of Gender ideology in the New Order public space. Bandung: Teen Rosdakarya.

VanDijk, A. Teun. 2009. Discourse Study: A multidisciplines of Introduction. $2^{\text {nd }}$ Edition. New Delhi: Sage Publication.

Yin, K. Robert. 2005. Case Study: Design and methods. Jakarta: PT. Raja grafindo Persada.

Zaprulkhan. 2015. philosophy of Science: a contemporaryanalysis. Jakarta: Eagle Pres

\section{List of scientific journals}

Cezar MAP *. 2014. Communication Within Group (I). ProQuest e reasourch (pnri.go.id)

Emirbayer, M and Johnson, V. 2008. Bourdeu and Organization Analysis. ProQuest e resourch (pnri.go.id)

Hebbani, A and Wills, C. 2012. How Muslim Woman in Australia Navigate Through Media (Mis) Representations of Hijab/Burqa. Proquest e reasourch (pnri.go.id)

Jackson, E. Kenneth and Turner, E. 2015. The Meaning of Hijab: Voice of Moslem Women in Yamen and Egypt ProQuest (pnri.go.id).

Lauzicre, H. 2010. The Construction of Salafiya: Reconsidering Salafism From Perspetive of Conceptual History. Proquest e reasourch (pnri.go.id)

O'donnell, R. Clifford and Tharp, G. Roland. 2011. Integriting Cultural Community Psicology: Activity Setting and The Shared Meanings of Intersubjective. Proquest e reasourch (pnri.go.id)

Rinaldo, R. 2012. Muslim woman Moral Vision: Globalization and Gender Controversies In Indonesia. ProQuest (pnri.go.id).

Shechtman, Z; Hiradin, A; Zina, S. 2003. The Impact of Culture on Group Behaviour. ProQuest e reasourch (pnri.go.id)

Umolu, O. Adaeze. 2014. Gender in race IN UK Organisation: Case Study of Nigerian and Indian Women. National Institute for Legislative Studies National Assambly, Abuja, Nigeria. ProQuest (pnri.go.id). 